Artikel Penelitian

\title{
Ekstrak Etanol Buah Semangka (Citrullus lanatus) sebagai Antiinflamasi melalui Pengamatan Tebal Epitel Duodenum Mencit BALB/c
}

\section{Ethanol Extract of Watermelon (Citrullus lanatus) as an Anti-Inflammatory through Observation on Duodenal Epithelial Thickness of BALB/c Mice}

\author{
SNN Makiyah ${ }^{1}$, Rizka Ulfatin $A^{2}$ \\ ${ }^{1}$ Bagian Histologi Fakultas Kedokteran dan Ilmu Kesehatan Universitas Muhammadiyah Yogyakarta \\ ${ }^{2}$ Program Studi Pendidikan Dokter Fakultas Kedokteran dan IImu Kesehatan Universitas Muhammadiyah Yogyakarta
}

\begin{abstract}
ABSTRAK
Buah semangka (Citrullus lanatus) mengandung senyawa flavonoid. Flavonoid bermanfaat sebagai agen antiinflamasi. Potensi antiinflamasi ekstrak etanol buah $C$. Ianatus terhadap ketebalan epitel duodenum mencit BALB/c belum pernah diteliti. Penelitian ini bertujuan untuk mengetahui perubahan ketebalan epitel duodenum mencit BALB/c diinduksi ovalbumin setelah pemberian ekstrak etanol buah Citrullus lanatus (EECL). Jenis penelitian ini adalah eksperimental in vivo pada hewan uji dengan posttest only control group design. Tiga puluh ekor mencit BALB/c jantan dibagi enam kelompok. Kelompok kontrol (normal, negatif, metilprednisolon) dan kelompok perlakuan EECL dosis $175 \mathrm{mg} / \mathrm{kg}$ bb, $350 \mathrm{mg} / \mathrm{kg} \mathrm{bb}$, dan $700 \mathrm{mg} / \mathrm{kgbb}$. Perlakuan EECL dan metilprednisolon diberikan selama 28 hari berturut-turut. Ovalbumin diberikan secara intraperitoneal pada hari peroral ke-15 dan ke-22 dan hari ke-23 hingga ke-28. Pada hari ke29, mencit dikorbankan dan duodenum dibuat preparat histologi dengan teknik pewarnaan Hematoxylin Eosin. Efek antiinflamasi EECL dinilai dari tebal epitel duodenum. Data tebal epitel duodenum dianalisis menggunakan one-way ANOVA dilanjutkan uji Tukey. Hasil penelitian menunjukkan tebal epitel duodenum tertinggi adalah kelompok kontrol normal 20,02 $\pm 3,50 \mu \mathrm{m}$ dan kelompok kontrol negatif memiliki tebal epitel duodenum terendah $15,98 \pm 3,22 \mu \mathrm{m}$. Pemberian EECL dosis 175, 350, dan $700 \mathrm{mg} / \mathrm{kg}$ bb serta metilprednisolon meningkatkan tebal epitel duodenum secara bermakna $(p<0,05)$. Tebal epitel duodenum kelompok perlakuan EECL dosis $350 \mathrm{mg} / \mathrm{kg}$ bb tidak berbeda bermakna $(p>0,05)$ dengan tebal epitel duodenum kelompok kontrol normal dan kelompok metilprednisolon. Disimpulkan bahwa ekstrak etanol buah Citrullus lanatus mampu meningkatkan ketebalan epitel duodenum BALB/c diinduksi ovalbumin dengan dosis efektif EECL $350 \mathrm{mg} / \mathrm{kg}$ bb sehingga berpotensi sebagai agen antiinflamasi.
\end{abstract}

Kata Kunci: Agen antiinflamasi, Citrullus lanatus, epitel duodenum, ovalbumin

\begin{abstract}
Watermelon (Citrullus lanatus) contains flavonoids compound. Flavonoids are useful as anti-inflammatory agents. The potency of anti-inflammatory in ethanol extract of watermelon on duodenal epithelial thickness of BALB/C mice has not been proven yet. This study aimed to determine the changes of duodenal epithelial thickness of BALB/c mice induced with ovalbumin after administrated with $C$. lanatus ethanol extract (CLEE). The type of this study was experimental in vivo on animal with post-test only control group design. Thirty male BALB/c mice were divided into six groups, i.e. control groups (normal, negative, methylprednisolone) and CLEE treatment groups (doses of $175 \mathrm{mg} / \mathrm{kgBW}, 350 \mathrm{mg} / \mathrm{kgBW}$, and 700 $\mathrm{mg} / \mathrm{kgBW}$ ). CLEE and methylprednisolone were administered for 28 consecutive days. Ovalbumin was administered intraperitoneally on day $15^{\text {th }}$ and $22^{\text {nd }}$ and orally on day $23^{\text {rd }}$ until $28^{\text {th }}$. On day $29^{\text {th }}$, the mice were sacrificed, and their duodenums were taken for histological preparations with Hematoxylin Eosin staining technique. Anti-inflammatory effect of CLEE was assessed from duodenal epithelial thickness. Data on epithelium thickness were analyzed using One Way ANOVA and followed by using Tukey test. The results showed that the thickest duodenal epithelial was in the normal control group $(20,02 \pm 3,50 \mu \mathrm{m})$, while the negative control had the thinnest duodenual epithelial $(15,98 \pm 3,22 \mu \mathrm{m})$. The administration of CLEE at doses 175,350 , and $700 \mathrm{mg} / \mathrm{kgBW}$ and methylprednisolone significantly increased duodenal epithelial thickness $(p<0,05)$. The thickness of duodenum epithelial of the group given CLEE dose of 350mg/kgBW was not significantly different with those of normal and methylprednisolone groups. It is concluded that the effective dose of $350 \mathrm{mg} / \mathrm{kg}$ bw Citrullus lanatus ethanol extract increases the thickness of duodenal epithelial of ovalbumin-induced BALB/C mice, so it has a potential as an anti-inflammatory agent.
\end{abstract}

Keywords: Anti-inflammatory agent, Citrullus lanatus, duodenal epithelial thickness, ovalbumin

Korespondensi: SNN Makiyah. Bagian Histologi Fakultas Kedokteran dan Ilmu Kesehatan Universitas Muhammadiyah Yogyakarta, JI.

Brawijaya, Tamantirto, Kasihan, Bantul, DIY55183 Tel. (0274)387656Email:nurul_makiyah@umy.ac.id 


\section{PENDAHULUAN}

Alergi makanan merupakan gejala yang mengenai banyak organ atau sistem organ dikarenakan hipersensitivitas terhadap makanan tertentu yang sebagian besar diperantarai reaksi hipersensitivitas tipe I $(1,2)$. Prevalensi alergi meningkat dari tahun ke tahun. Tercatat peningkatan sebesar $18 \%$ kasus alergi pada anak dibawah 18 tahun sejak tahun 1997 hingga 2007 $(3,4)$.

Alergi pada saluran pencernaan dapat menyebabkan peradangan pada duodenum. Duodenum merupakan bagian yang paling pendek dari usus halus. Fungsi utama duodenum adalah menyerap isi lambung dan mengabsorbsi nutrien ke dalam kapiler darah dan lakteal limfe. Radang pada duodenum dapat memicu kerusakan epitel, edema vili, dan proliferasi sel Goblet. Kerusakan ini kemudian digambarkan dengan gejala klinis berupa mual, muntah, diare, nyeri perut dan hipotensi $(5,6)$.

Penggunaan tanaman sebagai agen antiinflamasi semakin meningkat, salah satunya adalah tanaman semangka. Tanaman semangka (Citrullus lanatus) merupakan tanaman yang dapat dimanfaatkan hampir semua bagian tanamannya termasuk daging buahnya. Daging buah Citrullus lanatus mengandung $92 \%$ air dan $6 \%$ glukosa sehingga sangat cocok untuk dikonsumsi di Indonesia yang beriklim tropis (7). Citrullus lanatus mengandung senyawa flavonoid. Flavonoid mempunyai manfaat sebagai agen antiinflamasi. Berbagai teori diajukan untuk menjelaskan mekanisme flavonoid sebagi antiinflamasi diantaranya dengan mengaktifkan antioksidan, menghambat enzim eicosanoid, dan memodulasi molekul proinflamasi. Flavonoid dapat mengatur pengeluaran sitokin proinflamasi sehingga dapat menekan respon imun (8).

Tujuan penelitian ini adalah untuk mengetahui potensi ekstrak etanol buah semangka (Citrullus lanatus) sebagai agen antiinflamasi melalui pengamatan ukuran tebal epitel duodenum mencit BALB/c diinduksi ovalbumin.

\section{METODE}

Penelitian ini merupakan penelitian eksperimental in vivo pada hewan uji dengan post-test only control group design (9). Hewan uji dalam penelitian ini adalah 30 ekor mencit galur BALB/c diperoleh dari Unit Pengelolaan Hewan Percobaan (UPHP) Universitas Gadjah Mada.

Mencit dibagi menjadi 6 kelompok dengan menggunakan teknik Simple Random Sampling (10). Jumlah anggota per kelompok ditentukan dengan rumus Federer sehingga didapatkan 5 ekor mencit setiap kelompok. Keenam kelompok tersebut terdiri dari kelompok kontrol normal (K-N), kelompok kontrol yang hanya disensitisasi dengan ovalbumin (K-OVA), kelompok kontrol yang disensitisasi dengan OVA dan diberi metilprednisolon $0,13 \mathrm{mg} /$ hari (K-MP), dan tiga kelompok perlakuan dengan pemberian ekstrak etanol buah C.lanatus dosis $175 \mathrm{mg} / \mathrm{kg}$ bb (K-P1), dosis $350 \mathrm{mg} / \mathrm{kg}$ bb (K-P2), dosis $700 \mathrm{mg} / \mathrm{kg}$ bb (K-P3).

Variabel bebas pada penelitian ini adalah pemberian ekstrak etanol buah Citrullus lanatus dosis $175 \mathrm{mg} / \mathrm{kg}$ bb, $350 \mathrm{mg} / \mathrm{kg}$ bb, dan $700 \mathrm{mg} / \mathrm{kg}$ bb selama 28 hari berturutturut. Variabel tergantung adalah ukuran tebal epitel duodenum mencit BALB/c. Variabel terkendali adalah mencit BALB/c jantan, umur 8 minggu, berat \pm 20 gram yang dilakukan aklimatisasi selama 1 minggu, dipelihara dalam kandang, pencahayaan yang sama, diberi pakan standar BR 1 dan minum akuades (9).

Ekstrak etanol buah Citrullus lanatus diperoleh dari daging buah Citrullus lanatus yang dijadikan simplisia kemudian diekstraksi dengan menggunakan metode maserasi dengan pelarut etanol $80 \%$ dan diuapkan pelarutnya sehingga didapatkan ekstrak kental (10). Ekstrak etanol buah Citrullus lanatus kemudian diberikan pada ketiga kelompok perlakuan dengan dosis $175 \mathrm{mg} / \mathrm{kg}$ bb, $350 \mathrm{mg} / \mathrm{kg}$ bb dan $700 \mathrm{mg} / \mathrm{kg}$ bb per hari selama 28 hari dengan menggunakan bantuan sonde $(11,12)$.

Mencit dibuat menjadi alergi saluran pencernaan (13) dengan sensitisasi ovalbumin secara intraperitoneal pada hari ke-15 dengan dosis $0,15 \mathrm{~mL}$ OVA dalam $\mathrm{Al}(\mathrm{OH})_{3}$ setiap mencit dari $2,5 \mathrm{mg}$ OVA yang dilarutkan pada $7,75 \mathrm{~mL}$ aluminium hidroksida dan pada hari ke-22 dengan dosis $0,15 \mathrm{~mL}$ OVA dalam akuades/mencit dari $2,5 \mathrm{mg}$ OVA yang dilarutkan pada $10 \mathrm{ml}$ akuades. Selanjutnya pada hari ke23 sampai dengan hari ke-28 diberikan OVA peroral dengan dosis $0,15 \mathrm{~mL}$ dalam akuades yang dibuat dari 2,5mg OVA dalam 2,5ml akuades. Mencit dikorbankan pada hari ke 29 kemudian diambil organ duodenum untuk dibuat preparat histologi dengan teknik pewarnaan Hematoxylin Eosin. Tahap terakhir adalah pengamatan preparat histologi duodenum mencit dengan mikroskop perbesaran 400 kali pada 4 lapang pandang dan setiap lapang pandang diukur tebal epitel duodenum dari 4 epitel.

Data penelitian ini berupa ukuran tebal epitel duodenum dengan satuan $\mu \mathrm{m}$. Data dianalisis menggunakan one-way ANOVA dan dilanjutkan dengan Tukey test untuk mengetahui letak perbedaan pengaruh antar kelompok perlakuan mencit BALB/c.

\section{HASIL}

Hasil pengukuran tebal epitel duodenum mencit BALB/C pada masing-masing kelompok dapat dilihat pada Gambar 1.
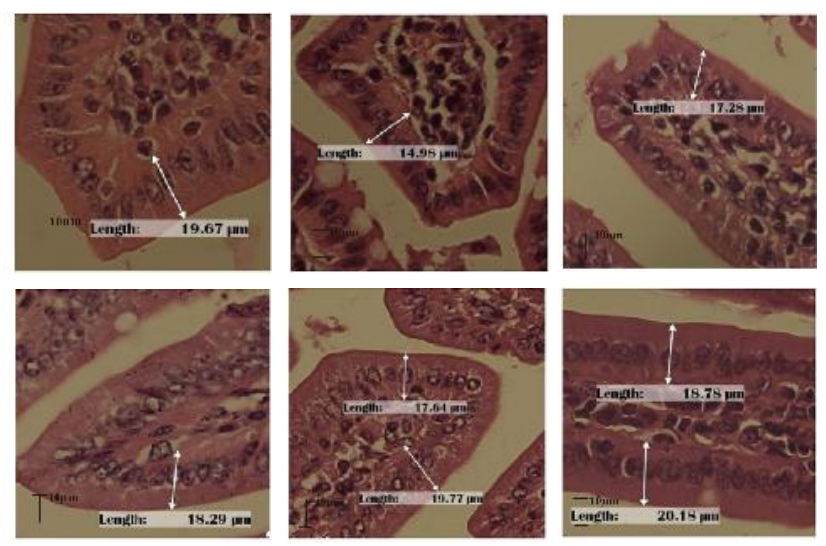

Gambar 1. Histologi tebal epitel duodenum mencit BALB/c dengan perwarnaan HE perbesaran 400x pada K-N (normal), K-OVA, ekstrak etanol buah Citrullus lanatus (EECL) dosis 175, $350,700 \mathrm{mg} / \mathrm{kg} \mathrm{bb}), \mathrm{K}-\mathrm{MP}$ 
Tabel 1. Rata-rata tebal epitel duodenum $(x \pm S D)$ dalam $\mu \mathrm{m}$ setelah pemberian ekstrak etanol buah Citrullus lanatus dosis $175,350,700 \mathrm{mg} / \mathrm{kg}$ bb selama 28 hari

\begin{tabular}{clc}
\hline No & Kelompok & Rata-rata \pm SD $(\mu \mathrm{m})$ \\
\hline 1 & K-Normal & $20,02 \pm 3,50^{\mathrm{d}}$ \\
2 & K-OVA & $15,98 \pm 3,22^{\mathrm{a}}$ \\
3 & EECL 175 & $7,46 \pm 3,50^{\text {abc }}$ \\
4 & EECL 350 & $19,03 \pm 4,47^{\text {cd }}$ \\
5 & EECL 700 & $17,17 \pm 3,58^{\text {ab }}$ \\
6 & K-MP & $18,44 \pm 3,03^{\text {bcd }}$ \\
\hline Keterangan:
\end{tabular}

menunjukkan tidak ada beda nyata antar kelompok $(p>0,05)$

Kelompok Normal (K-N) yang tidak diberi perlakuan apapun memiliki tebal epitel duodenum paling tinggi yaitu $20,02 \pm 3,50 \mu \mathrm{m}$. Kelompok kontrol negatif yang hanya diberi ovalbumin (K-OVA) memiliki tebal epitel duodenum paling rendah yaitu $15,98 \pm 3,22 \mu \mathrm{m}$. Kelompok perlakuan yang diberi ovalbumin dan ekstrak etanol buah Citrullus lanatus dosis $175 \mathrm{mg} / \mathrm{kg}$ bb, $350 \mathrm{mg} / \mathrm{kg}$ bb, $700 \mathrm{mg} / \mathrm{kg}$ bb mengalami peningkatan tebal epitel duodenum dibandingkan dengan K-OVA. Tebal epitel duodenum paling tinggi terjadi pada kelompok perlakuan EECL dosis $350 \mathrm{mg} / \mathrm{kg}$ bb (K-P2) yaitu $19,03 \pm 4,47 \mu \mathrm{m}$. Pada kelompok perlakuan EECL dosis $175 \mathrm{mg} / \mathrm{kg}$ bb (K-P1) memiliki tebal epitel duodenum 17,46 $\pm 3,50 \mu \mathrm{m}$ dan pada kelompok perlakuan EECL dosis $700 \mathrm{mg} / \mathrm{kg}$ bb (K-P3) memiliki tebal epitel duodenum $17,17 \pm 3,58 \mu \mathrm{m}$. Kelompok kontrol metilprednisolon (K-MP) juga mengalami peningkatan tebal epitel duodenum yaitu $18,44 \pm 3,03 \mu \mathrm{m}$.

Tebal epitel duodenum kemudian diuji normalitasnya menggunakan Kolmogorov Smirnov dan didapatkan hasil data normal $(p>0,05)$ kemudian dilanjutkan uji parametrik One Way ANOVA didapatkan nilai $p=0,00 \quad(p<0,05)$ menunjukkan bahwa rata-rata tebal epitel duodenum berbeda secara signifikan. Pemberian EECL dosis 175 $\mathrm{mg} / \mathrm{kg} \mathrm{bb}, 350 \mathrm{mg} / \mathrm{kg}$ bb, dan $700 \mathrm{mg} / \mathrm{kg}$ bb serta metilprednisolon meningkatkan tebal epitel duodenum secara bermakna $(p<0,05)$. Tebal epitel duodenum kelompok kontrol negatif yang hanya diberi ovalbumin tidak berbeda bermakna $(p>0,05)$ dengan kelompok perlakuan EECL dosis $175 \mathrm{mg} / \mathrm{kg}$ bb (K-P1) dan kelompok perlakuan EECL dosis $700 \mathrm{mg} / \mathrm{kg}$ bb (K-P3). Tebal epitel duodenum kelompok perlakuan EECL dosis $350 \mathrm{mg} / \mathrm{kg}$ bb tidak berbeda bermakna $(p>0,05)$ dengan tebal epitel duodenum kelompok kontrol normal dan kelompok metilprednisolon.

\section{DISKUSI}

Penelitian ini dilakukan untuk mengetahui efek antiinflamasi dari ekstrak etanol Citrullus lanatus. Semua kelompok kecuali kelompok normal (K-N) dibuat alergi inflamasi dengan cara pemberian ovalbumin secara intraperitoneal pada hari ke-15 dan hari ke-22 dilanjutkan dengan pemberian ovalbumin peroral pada hari ke-23 hingga hari ke-28. Pada kelompok yang hanya diberi ovalbumin saja (K-OVA) didapatkan rata-rata tebal epitel paling rendah yaitu $15,98 \pm 3,22 \mu \mathrm{m}$. Hal ini terjadi karena kerusakan pada epitel duodenum. Hal ini sesuai dengan penelitian yang dilakukan oleh Prasetyo pada tahun 2008 yaitu paparan ovalbumin kronik dapat meningkatkan derajat inflamasi pada duodenum mencit BALB/c (14).

Duodenum merupakan organ pencernaan yang menjadi tempat penyerapan pertama zat-zat nutrisi. Paparan zatzat tertentu pada duodenum dapat berefek pada kerusakan epitel mukosa duodenum. Kerusakan epitel duodenum dapat didefinisikan dengan melihat kedalamannya yaitu berupa erosi mukosa dan ulserasi mukosa. Erosi mukosa merupakan hilangnya sebagian ketebalan mukosa, sedangkan ulserasi mukosa adalah hilangnya seluruh tebal mukosa dan sering menembus lapisan yang lebih dalam. Kerusakan juga bisa dikarenakan kurangnya produksi mukus oleh kelenjar Brunner yang terdapat di submukosa duodenum yang berfungsi sebagai pelindung mukosa, aktivasi kelenjar Brunner dihambat oleh stimulus simpatis yang meningkat pada keadaan stres kronik yang disebabkan paparan ovalbumin (15).

Pada saluran pencernaan, paparan ovalbumin menyebabkan timbulnya alergi atau hipersensitifitas tipe I. Alergi dapat terjadi oleh karena terjadi ketikdakseimbangan hasil diferensiasi sel T CD4+ yaitu sel Th1 CD4+ dan sel Th2 CD4+. Sel Th1 CD4+ mensekresi Interferon- $\gamma$, Tumor Necrosis Factor dan limfotoksin yang berperan pada respon imun seluler, sedangkan sel Th2 CD4+ mensekresi interleukin-4 (IL-4), IL-5, IL-6, IL-10, dan IL-13 yang sangat berperan pada respon imun humoral. Pada alergi-inflamasi terjadi peningkatan sel Th2 CD4+ dan supresi sel Th1 CD4+. Paparan berulang ovalbumin meningkatkan sel limfosit CD4+ sehingga menstimulasi sel $B$ meningkatkan produksi IgE. Imunoglobulin E adalah antibodi yang sangat berperan pada reaksi alergi (16). Sitokin yang dihasilkan sel Th2 CD4+ akan memicu produksi sel mast dan basofil. Interaksi antara ovalbumin yang diberikan secara berulang dengan permukaan sel mast memicu terjadinya degranulasi sel mast, basofil, dan eosinofil sehingga dilepaskan mediator inflamasi dan akibatnya terjadi inflamasi (17). Salah satu sitokin yang dihasilkan oleh sel mast adalah histamin. Kadar histamin yang tinggi akan memicu peningkatan inflamasi pada lapisan mukosa usus. Pada kondisi ini terjadi ketidakseimbangan flora di usus oleh karena terlepasnya mediator-mediator inflamasi, maka terjadi kerusakan sistem barier mukosa usus yang mengakibatkan terjadi erosi epitel mukosa usus (15).

Pemberian ekstrak etanol buah Citrullus lanatus dosis $175 \mathrm{mg} / \mathrm{kg} \mathrm{bb}, 350 \mathrm{mg} / \mathrm{kg}$ dan $700 \mathrm{mg} / \mathrm{kg}$ selama 28 hari berturut-turut dapat meningkatkan tebal epitel duodenum karena pada buah Citrullus lanatus terkandung metabolit sekunder yang kaya manfaat salah satunya adalah flavonoid. Flavonoid merupakan kumpulan senyawa polifenol yang memiliki karakteristik dan susunan kimia yang beragam. Saat ini ada lebih dari 9000 jenis flavonoid yang ditemukan di dalam tanaman. Manfaat flavonoid sangat beragam salah satunya adalah sebagai agen antiinflamasi (18).

Mekanisme flavonoid sebagai antiinflamasi melalui berbagai jalur diantaranya adalah dengan aktivitas antioksidan yaitu radical scavenging, menghambat produksi ROS (Reactive Oxygen Species), dan mennghambat enzim prooksidan sehingga menurunkan radikal bebas dan lipidic peroxidation. Mekanisme kedua adalah modulasi enzim proinflamasi yaitu asam arakhidonat dan NO (Nitric Oxide) sehingga menurunkan mediator inflamasi seperti NO, leukotriens dan prostaglandin. Mekanisme ketiga adalah modulasi mediator proinflamasi sehingga menurunkan sitokin proinflamasi seperti TNF- $\alpha$ dan leukotrien. Mekanisme yang terakhir adalah dengan modulasi gen proinflamasi 
dengan menghambat sinyal transduksi sehingga menurunkan modulasi transkripsi gen $(19,20)$.

Kelompok perlakuan yang diberi ekstrak etanol buah Citrullus lanatus mengalami peningkatan tebal epitel duodenum dibandingkan K-OVA dengan tebal epitel duodenum yang paling mendekati normal terjadi pada KP2 yaitu kelompok ekstrak etanol buah Citrullus lanatus dengan dosis $350 \mathrm{mg} / \mathrm{kg}$ bb. Hasil penelitian ini membuktikan bahwa buah Citrullus lanatus memiliki efek antiinflamasi dengan meningkatkan tebal epitel duodenum mencit. Hasill penelitian ini sesuai dengan penelitian yang dilakukan oleh Niwanggalih pada tahun 2014 bahwa pemberian ekstrak kulit buah Citrullus lanatus dapat menurunkan jumlah netrofil pada mencit BALB/c yang mengalami luka gores (21).

Pemberian metilprednisolon juga meningkatkan tebal epitel duodenum mencit. Salah satu efek metilprednisolon dalam tubuh adalah sebagai antiinflamasi. Metilprednisolon dapat mengurangi efek inflamasi karena metilprednisolon adalah golongan obat antiinflamasi steroid adrenal yang bekerja dengan cara menghambat aktivitas enzim fosfolipase A2. Metilprednisolon menghambat enzim lipooksigenase yang berperan pada pembentukan asam arakhidonat sehingga mediator-mediator inflamasi dan nyeri tidak terbentuk (22).

\section{DAFTAR PUSTAKA}

1. Tanukusumah M, Kurniati N, Chozie NA. Prevalensi Alergi Makanan pada Anak Usia Kurang Dari 3 Tahun di Jakarta Berbasis Survei dalam Jaringan/Online. Sari Pediatri. 2015; 16(5): 365-374.

2. Branum AM dan Lukacs SL. Food Allergy Among U.S. Children: Trends in Prevalence and Hospitalizations. Centers for Disease Control and Prevention's National Center for Health Statistics. 2008; 10: 1-8.

3. Wistiani HN. Hubungan Pajanan Alergen terhadap Kejadian Alergi pada Anak. Sari Pediatri. 2011; 13(3): 185-190.

4. Barlianto W, Kusuma MSC, Karyono S dan Mintaroem K. Pengembangan Model Mencit Alergi dengan Paparan Kronik Ovalbumin. Jurnal Kedokteran Brawijaya. 2009; 25 (1) : 1-5.

5. Mollica JQ, Cara DC, D'Auriol M, Oliviera VB, Cesar IC, and Brandao MGL. Anti-inflammatory Activity of American Yam Dioscorea trifida L.f. in Food Allergy Induced by Ovalbumin in Mice. Journal of Functional Food. 2013; 5(4): 1975-1984.

6. Alper A, Hardee S, Rojas-Velasquez D, Escalera S, Morotti RA, and Pashankar DS. Prevalence and Clinical, Endoscopic, and Pathological Features of Duodenitis in Children. Journal of Pediatric Gastroenterology and Nutrition. 2016; 62(2): 314316.

7. Pardede TR dan Muftri DSS. Penetapan Kadar Kalium, Natrium dan Magnesium pada Semangka (Citrullus vulgaris, Schard) Daging Buah Berwarna Kuning Dan Merah Secara Spektrofotometri Serapan. Jurnal Darma Agung. 2010; 2(1): 1-7.

8. Khaki A, Fathiazad F, Nouri M, dan Khaki AA. Effect of
Pemberian ekstrak etanol buah semangka (Citrullus lanatus) dosis $175 \mathrm{mg} / \mathrm{kg}$ bb, $350 \mathrm{mg} / \mathrm{kg} \mathrm{bb}, 700 \mathrm{mg} / \mathrm{kg}$ bb mampu meningkatkan tebal epitel duodenum mencit Balb/C yang diinduksi ovalbumin. Rata-rata tebal epitel pada kelompok yang diberi ekstrak Citrullus lanatus dosis $350 \mathrm{mg} / \mathrm{kg}$ bb tidak berbeda secara bermakna tebal epitel pada kelompok kontrol normal dan kelompok kontrol metilprednisolon. Ekstrak etanol buah Citrullus lanatus dosis $350 \mathrm{mg} / \mathrm{kg}$ bb merupakan dosis terbaik yang mampu meningkatkan tebal epitel duodenum secara efektif oleh karena dengan peningkatan dosis ekstrak etanol buah Citrullus lanatus menjadi $700 \mathrm{mg} / \mathrm{kg}$ bb atau penurunan dosis ekstrak etanol buah Citrullus lanatus dengan dosis $175 \mathrm{mg} / \mathrm{kg}$ bb juga terjadi peningkatan tebal epitel duodenum tetapi peningkatan dan penurunan dosis ekstrak etanol buah Citrullus lanatus tersebut secara statistik tidak berbeda bermakna dengan kelompok kontrol yang diberi ovalbumin, meskipun tidak berbeda bermakna dengan kelompok kontrol yang diberi metilprednisolon. Ada faktor dose-dependent pada pemberian ekstrak etanol buah Citrullus lanatus ini. Disimpulkan bahwa ekstrak etanol buah Citrullus lanatus mampu meningkatkan ketebalan epitel duodenum BALB/c diinduksi ovalbumin dengan dosis efektif ekstrak etanol buah Citrullus lanatus $350 \mathrm{mg} / \mathrm{kg}$ bb sehingga berpotensi sebagai agen antiinflamasi.

Citrullus lanatus Seeds Extracts on Serum Total Testosterone in Rat. Crescent Journal of Medical and Biological Sciences. 2014; 1(1): 25-27.

9. Prinarbaningrum A dan Makiyah SNN. Derajat Peradangan Duodenum Mencit BALB/C setelah Pemberian Ekstrak Etanol Ubi Jalar Ungu (Ipomoea batatas L.) Diinduksi Ovalbumin. Jurnal Kedokteraan dan Kesehatan Mutiara Medika. 2016; 16(1): 1-8.

10. Senja RY, Issusilaningtyas E, Nugroho AK and Setyowatu EP. The Comparisson of Extraction Method and Solvent Variation on Yield and Antioxidant Activity of Brassica oleracea L. var capitata f. rubra Extract. Traditional Medicine Journal. 2014; 19(1): 43-48.

11. Makiyah SNN, Noor Z, Widodo N, Rifa'i M, and Djati MS. Ethanol Extract of Tubers Diocora Alata $L$ as Antiallergic Agent on Mice BALB/c Induced with Ovalbumin. International Journal of Pharma and Bio Sciences. 2014; 5(3): 214-220.

12. Kantham S. Influence of Carica Papaya Linn Extracts on Paracetamol and Thioacetamide Induced Hepatic Damage in Rats. The Internet Journal of Pharmacology. 2009; 9(1): 1-6.

13. Fischer R, McGhee JR, Vu HL, et al. Oral and Nasal Sensitization Promote Distinct Immune Responses and Lung Reactivity in a Mouse Model of Peanut Allergy. The American Journal of Pathology. 2005; 167(6): 1621-1630.

14. Prasetya DH, Endang LS, dan Subijanto AA. Pengaruh Probiotik terhadap Gambaran Histologis Mukosa Usus pada Mencit BALB/c Model Alergi. Jurnal Kedokteran Yarsi. 2008; 16(1): 6-12.

15. Wahab RA, Suharto G, dan Margawati A. Pengaruh Formalin Peroral Dosis Bertingkat Selama 12 
Minggu terhadap Gambaran Histopatologis Duodenum Tikus Wistar. Jurnal Kedokteran Diponegoro. 2012; 1(1):1-13.

16. Subijanto AA dan Diding HP. Pengaruh Minyak Biji Jinten Hitam (Nigella sativa L.) terhadap Derajat Inflamasi Saluran Napas. Majalah Kedokteran Indonesia. 2008; 58 (6): 200-204.

17. Baratawidjaja KG dan Rengganis I. Imunologi Dasar. Jakarta: Badan Penerbit Fakultas Kedokteran Universitas Indonesia; 2014.

18. Xiao ZP, Peng ZY, Peng MJ, Yan WB, Ouyang YZ, and Zhu HL. Flavonoids Health Benefits and Their Molecular Mechanism. Mini Reviews in Medicinal Chemistry. 2011; 11(2): 169-177.

19. García-Lafuente A, Guillamón E, Villares A, Rostagno MA, and Martínez JA. Flavonoids as AntiInflammatory Agents: Implications in Cancer and
Cardiovascular Disease. Inflammation Research. 2009; 58(9): 537-552.

20. Oseni OA and Okoye VI. Studies of Phytochemical and Antioxidant Properties of the Fruit of Watermelon (Citrullus lanatus). (Thunb.). Journal of Pharmaceutical Biomedical Science. 2013; 27(27): 508-514.

21. Niwanggalih P, Waluyo J, dan Asyiah IN. Pengaruh Ekstrak Kulit Semangka (Citrullus Lanatus (Thunb.)) terhadap Jumlah Neutrofil pada Radang Luka Gores Mencit (Mus musculus) Jantan BALB/C dan Pemanfaatannya sebagai Karya Ilmiah Populer. Artikel IImiah Mahasiswa UNEJ. 2014; 1(1): 1-4.

22. Benowitz NL. Obat Antihipertensi. Di dalam: Katzung BG (Ed). Farmakologi Dasar dan Klinik (Basic \& Clinical Pharmacology) Buku 1 edisi 10. Jakarta: EGC; 2007. 